\title{
TEACHING A GIFTED AND CREATIVE PUPIL AND STUDENT
}

\author{
JAKUBIAK-ZAPALSKA Ewa - ZAPALSKA Ewa, PL
}

\begin{abstract}
„It is in our sincere hope to embrace every talented human being with care, no matter of the economic environment they were brought up to this world into. We are going to take any measure to prevent those talented people to get wasted and go purposelessly through life, being devoted of the appropriate and wise care and education."
\end{abstract}

Thomas Jefferson

\begin{abstract}
Today most scientists recognize a gifted student as a student with special educational needs. A gifted student has different from their classmates possibilities, expectations and problems. They usually have no problems with school education (at least at the beginning of it), but they often need special support and sometimes even therapeutic intervention. In the context of the problem: SEN (special educational needs) - outstanding ability, it is worth considering students with disabilities. Is it possible to treat students with disabilities in Polish schools as gifted persons/children?
\end{abstract}

Key words: exceptional talent, special ability, gifted student, special educational needs, school. teacher

\section{NAUCZYCIEL UCZNIA, STUDENTA ZDOLNEGO I TWÓRCZEGO}

\section{Resumé}

Współcześni naukowcy zajmują się problematyką ucznia i studenta ze specjalnymi potrzebami edukacyjnymi. Uczeń / student zdolny ma inne niż jego koledzy możliwości, oczekiwania i problemy. Zwykle nie mają oni problemów z edukacją szkolną (przynajmniej w początkach edukacji), ale zwykle potrzebują specjalnego wsparcia, a czasami nawet interwencji terapeutycznej. Zwykle za uczniów ze specjalnymi potrzebami edukacyjnymi uważa się raczej uczniów w jakiś sposób dotknietych niepełnosprawnością, jednak chyba warto szerzej traktować kategorię uczniów ze specjalnymi potrzebami edukacyjnymi.

Słowa kluczowe: uczeń zdolny, uczeń utalentowany, zdolny student, specjalne potrzeby, szkoła, nauczyciel.

\section{Introduction}

It is an important educational goal of any university to unleash the creative tendencies of the students and to enable them to realise successfully their skills in the most comfortable conditions possible, in accordance to their needs. The following publication touches upon the problem both of social and cultural conditioning of creativity, characteristic for high schools. For that reason, the establishments concerning the enviromental stimulises and creativity inhibitors have been revised. Secondly, the student's forms of practical activity, completing the academic education, have been presented. In spite of many charges against school (independently from its level of education), it may possibly become the institution educating the students about creativity and enabling them both to feel and develop it. In accordance to the titular subject's problematics, it is especially important to 
answer the groups of questions, that, on the surface, may seem not to be connected with each other. The first group of questions: if a student/pupil is de facto considered as the special educational needs student/pupil by the teachers. Is it possible to accept them into the special needs group of people, basing on the research conducted in accordance with the problem's area? The student's development activation process is dependent from all the factors, that determine the academic teacher's work, such as their competence, the accepted type of the didactic work (for example, "me" type of communication, the methods in use and the didactic means). The article is restricted to the publications focused on the skillful type of students only.

\section{The academic teacher competences}

"Competence is the ability of executing the specified task on the expected level. (...) It is a result of integrating knowledge with huge amount of tiny skills and effective values' calculation“" (1). The competences may be simply divided on: merithorical, methodical and psychological. Refering to the definition above, the exposed competences should not be considered as permanent features. The process of acquiring those competences and their development is dependent from the "me" awarness as an academic teacher in relation to the overall teaching - learning process. All of the competences: the meritorical (the knowledge and skills concerning the specific area), methodical (the overall didactic process in high school) and psychological one (being familiarized with phrases, like subjectivity, holism, communication, active listening, pedagogical approach and so on) supplement each other. The more an academic teacher is aware of them, the more precise their affection is - in this case, their cooperation with the group of students. In case of one of the competences having an advantage over the other onces, the process of student's activation during the organised didactic practices is faulty. While making research over the situation (basing on the inspection of the didactic activities in high school on two post-graduate study directions, it turns out that majority of the staff is well-prepared in terms of the meritorical competences, while the methodical and psychological ones are neglected. „The lack of psychological competences is clearly noticeable in the teaching style the academic teacher accepts (it concerns the authoritative and liberal style). The democrative style makes the teaching - learning process, in other words the interaction between a teacher and a learning subject, the most effective" (10).

This process requires to make specification about the regulations and principles valid during the planned classes (5). The pedagogical knowledge, a stable collection both of scientific and practical generalizations and the pedagogical experience, is a natural basis for commitment of the actions, serving the educational transitions. This kind of knowledge is supplemented with the similar sciences' experience - including philosophy, psychology and sociology above all. Such a knowledge becomes an inspirational force for the other educational transformations, taking into consideration all the educational system. The phenomenon may be noticed through emergence of the educational methods and in the overall scale of single schools, single teachers and tutors, which is expressed in the form of the pedagogical innovations.

In case of the high school didactics, the academic teacher should know, that the didactic process depends from the ability to interest with a specific subject and the process of making suitable directions towards the student in every form of the classes realization. For this reason, the importance of teaching - learning interaction is emphasized by the teacher. Without the student, the teacher's position has no reason to be. Having accepted the suitable attitude towards their subject and the group they cooperate with, the teacher leads to significant increase of the students' engagement in the subject. This phenomenon is proved by the self-evaluation process the students commit during the internship. The introduction to the subject must be discussed in a detailed way, including the detailed pieces of information, concerning what will be laid out for the specific topic and the core meaning of the specific content so the whole sense of the discussed contents in the 
specific specialization is easier to understand. Unfortunately, such an approach as well as the general evaluation of the teacher's work both on the methodical and substantive angle, are rare.

Every teacher can become an innovator and a new educational methods' creator (20, p. 40).

\section{Teacher work with talented pupil and student - review of the literature}

There are many definitions concerning the meaning of the "skills" word. S. Popek has created a collection of explanations, created by different authors. The first one reffers to treating them as: the abilities' synonymus, fluency and quickness either of the result or outcome; greater capacity of memory; greater quality, deep and broad analysis or sintezis, in other words - as the understanding process.

The second explanation concerns the ability to understand them as: the actual possibility to do some task: the potential fluency acquisition in the activity the subject has not acquired yet; to the maximal acheivement level; to the properties the entity may acquire thanks to his or her natural makings.

The third approach revolves around the relatively permanent features of the recognition processes, determining the high lebel of the entity's acheivements. The fourth group includes the abilities typicall for an individual human beings (22, pp. 22-23).

As W. Okon explains, from the psychological point of view, ability is the opportunity to acquire the expected results while conducting specific activities in specified external conditions. (...) The list of general abilities consists of: perceptiveness, productive thinking, imagination, memory, caution and motor skills $(16$, p. 463). It treats ability as the right decisions making skill. It is necessary to conduct the skills ability recognition research on children.

A common feature among the skillful students and pupils is the IQ level of 130. Such a group is usually recognized for their easiness in the educational progress, exemplary special skills and in having wide range of hobbies. They have tendencies to be strict, to dominate and to serve as leaders. Moreover, they are initiative, active and self-sufficient (25, p. 15).

Nowadays, modern high schools are known for being focused mainly on average students' development. Various agents are applied to meet with those students' requirement, the materials, the teachers' expectations and the work pace during the classes included. The "skillkul student" term concerns the entities with the high level of general abilities (the intelligence) or those, that have some special ability, relating them to the mental or physical activity. Usually, they either have the exceptional acheivements or potential skills for such an activity.

The student with the exceptional abilities may be recognised through:

- their tendency for an effective progress in acquiring new abilities and exemplary, outstanding results in the specified activity,

- creative thinking and action, wide range of the recognition skill

- high level of the analitical thinking,

- easiness in understanding and valid usage of abstract symbols and symbolic relationships

- using symbols by one's own,

- the ability to concentrate, especially in the area of the abstract content,

- the ability to recognize problems and patience in solving them,

- the instances of satisfaction coming from solving the problems and intelectual difficulties' overcome.

The exceptional abilities may be exposed on different fields:

- scientific,

- artistic,

- rechnical,

- sport activity, 
- social life (a student exposes the talent in leadership or in coming up with an efficient solution for social problems).

The skillfull student rarely does have the individual studying system at his disposal and the overall amount of facultative courses is getting reduced.

There is a lot of situations in high schools, in which students require the specific kind of support. Those situations include: the initial stage of studying in new school, exhaustion being the result of the undertaken obligations (taking part in various competitions and olimpics simultaneously), multiplicity of the additional education directions, problem with finding oneself in the group and lack of acceptation of the top students by their colleagues. In this area, a teacher is the appropriate person, having opportunity to recognize the difficulties of this type and to undertake specific actions against them (4, pp. 26-27).

E. Jakubiak - Zapalska noticed that the development of the talented student requires the utilisation of various methods (9, pp. 224-232). However, the observation is considered to be the most appropriate method, applied for variety of situations. It enables to recognize the most important features of a student. Those specific features may be easily noticed in the children in the kindergarden age. If the parents care about their child, they should be able to do it, as well as the teachers and nursery teachers. The process is conducted on the basis of getting to know the child. This process is obligatory when it comes to teachers. The reason for that is because it is the most appropriate moment to notice the child's skills.

The first teacher is the most important person in the child's life, being remembered by them long after graduation and systematic education completion, which makes the teachers burdened with an exeptional responsibility. The unfortunate fact is there are the teachers, that tend to neglect the gifted students, to mock them in front of the whole classroom and to expose the agressive attitude towards them. As a result, the gifted student may become blocked, discouraged for further work and have their education results deteriorate. An academic teacher should understand the necessity of supporting even the gifted student, taking into consideration their requirements and abilities. During the stimulative progress process of the ward, all the spheres of his life - the cognitive, emotional, physical, social and spiritual one should be taken into consideration (7).

The importance of recognizing and supporting skills in students or pupils by the teacher in the most early stage possible is undisputable. Many of the teachers are not willing to undertake the task because of the amount work they have to put into the task. All that is required from a teacher is goodwill, motivation, the ability to inspire young people during their practical education, preparing them for being employed as teachers. The teachers without the sense of mission become indifferent towards the children's needs. Because of the feeling of being forced to do their responsibility, they put much less effort and attention into the children's development. As a result, the more gifted children do not receive their attention (8). All the children come to the world, being already equipped with their creativity skills. In the later stages, their further progress is dependent from the adults. The conducted research pointed out, that the significant percentage of skilled students does not acheive satisfactory results in the educational process, working below their potential $(2$, p. 21$)$.

\section{The creative personality and the creative thinking}

The creative attitude motivates the interior power, inspires and ennobles, giving a man the chance to prove his place in the world. Each action of theirs, every creative deed acquires its value for what it is. "It is not tradition, development, past nor future, that are the measure of human actions, but perfectness" (there in, p. 23).

Creativity may be considered as a heroic attitude, to some extent as an element, that requires stepping beyond consumption and carnivalesque, as well as being corageous and overcome the obstacles; however, it does not require the rebelious heroism, its abruptness and impetuousness and 
the necessity of bringing destruction towards the other human beings. According to M. Olczak, creative attitude stands for the openess of the mind. It is moulded thanks to its own creative activity; yet, the correct process of the mind formation is significantly influenced through contact with art, technical devices, emotional approach, understanding, interpretation and assessment of aesthethical and technological phenomenons are of great value in forming this attitude. The creative attitude is considered as the creation disposition every human being has, no matter of their age; its structure is based on three elements: the recognition one, the one, that combines emotional, motivational and the active attitude one $(17,18)$. Both of the creative personality and creative thinking are also influential when it comes to choosing the profession. Hence, it is possible to mention about the requirements, that are specific for various professions (19). The creativity/output description invokes two „dimensions", based on A. Cropley's systematization, that embraces both of creative thinking (the associative conceptions, i.e. J.P. Guilford, Klaus K. Urban and Hans G. Jellen) and the creative person's properties (the assosciative conceptions by S. Popka and K. Krasoń). Both of the personality and thinking may refer to the creative skills' conceptions, usually established in form of three paradigms, treating the creativity as: the divergence-way of thinking, the associative and metaphorical one. The conception of the divergence thinking refers to Joy P. Guilford, who distinguished the divergence and convergence-way of thinking. Fluency (fluency - multiplicity, flexibility - variety, originality - the rarity of ideas) is important. Generally, fluency stands for the efficient productivity of various solutions and connotations, being of the verbal, connotative, expressional or ideational type. Flexibility stands for the ability to create various solutions, ideas and connotations. It may be of spontaneous or adaptational character.

"Originality is the ability to create solutions, ideas or specific, unique or rare connotations. In terms of the associative thinking, creativity is connected with the process of creating new units, links or connotative combinations (i.e. using the specific devices for completely new purposes, the discovery of similarities between the devices, subjecting different objects to specific classes, enriching various sets of lines and patterns with meaning). The productivity assessment refers in this case to the overall amount of the ideas and their originality. From the metaphorical approach, creativity is the ability to join the distant areas of experience" $(11$, p. 51$)$, basing on the similarities between them. All of the processes, such as concentration and engagement, concentration on the specific topic, perserverance, persistance are the features of human personality, enabling to have clearer perception on the surrounding world and to shift from motivation to action. They are the basic elements for attention, memory and learning process development, that lead to relatively permanent changes in the entity's behaviour, as the result of their precious experience. Concentration is the so called free attention, taking place when a subject is consciously focused on some object or phenomenon because of the meaning the significance of the object. From the subject's point of view, it is either important or intresting. Being focused on one object enables us to do few activities simultaneously, to track different independent, yet equally important processes.

The creative attitude is influenced by own individual creative expression, initiated by the art-for-art education.

\section{The teacher's work with gifted pupil or gifted student}

The purpose of teaching is influence on student's educational development. They have to be sufficiently prepared, so as to be sufficient in this task. What is the measure of their readiness to pedagogical work? As M. Bałażak explains, (1, pp.182-183) "The crucial element here is the teacher's preparation for the profession. In case of this profession, the teaching process is based on the activities conducted throughout the whole duration of their career. While working with students, the teacher supplements his or her own knowledge, improves his or her own skills and boosts up the 
level of the student's pedagogical knowledge, legitimating them to teach. Additionally, they undertake various actions, enabling them to understand the school and their own reality.

"It is the teachers' task to reach the others, to get closer, to make a research and to observe so as to educate them. All the teachers' actions and task they undertake revolve around the students' good".

In order to motivate the students sufficiently to proceed their education, the teacher is obliged to know them. Its a two-way activity of showing the personal stock of the wards: by knowing them better, a teacher is able to show them their hidden abilities the students did not know about themselves". Not all teachers and psychologists are able to work with gifted students. A significant group of the gifted students learns below their intelectual abilities. Very frequently, they do not meet with the school's requirements $(14$, p. 51$)$.

A. Sękowski makes a few suggestions for teachers about how to help their gifted students:

- to notice abilities in all the students,

- to "extract" those with the exceptional abilities,

- to create the opportunities for the individual teaching at schools for all,

- to support the contact of the gifted students with other gifted students,

- to encourage them to Olympic activity,

- to cooperate systematically with the gifted student's parents,

- to support sustainable development of the student, not only intellectual but also emotional and social one,

- to appreciate their abilities, to emphasize their achievements and further abilities - in other words, to motivate them to have the achievements,

- to correctly establish their value hierarchy, so that their achievements have higher goal than being just satisfactory source,

- to look for an interesting material, that will focuses the gifted student's/pupil attention - to inspire;

- to accept the fact that a student may exceed their teachers in some connotations or integrating ideas,

- to organize the meetings with the teachers having the exceptional achievements in some fields; to develop the psychological knowledge of the students,

- to develop the gifted student's knowledge about themselves,

- to develop the polite attitude of the student in terms of the surrounding; to bring up the issues, that concern both of skills and wisdom (24).

An individual system of rules concerning the work with a gifted student should be established. Many gifted students expect from their teachers to be supportive. In order to have a contribution in the students' development, the teacher should begin the process from learning about their students' requirements. Only then it is possible to broaden the students' intelectual side. The action plan should be established. Even though it is the teacher, who should propose the work methods with the student, the choice of the suitable methods should be made by both sides. The creation of comfortable development conditions should be simultaneous to the suitable motivation to work, appreciation of independence and the originality of thinking, focusing not only on the effects, but also on the course of the work. The difficulty level of the given tasks should be systematically raised, so that they pose an intelectual challenge for the student, in accordance to his abilities. The students should be constantly reminded that the challenge they are undertaking makes sense. Any achivements should be awarded. The didactic work takes place in various organisarional structures, including special programs or the individual course of the studies. Such an approach enables to apply a suitable pace of learning and to choose the contents of teaching. The individual course of studies makes it possible to pass the material any time. It is also possible to learn the 
material content from different subject in various pace, i.e. faster pace for the subject of interest. The other subjects are then realised in accordance to the program. In this way, the students have the opportunity to learn in terms of six months the material, that was planned to be realised in terms of the whole year. To sum it up, the two-year material may be covered in two terms.

Joint work of student and teacher is very advantegous. By deepening the students' interest with the subject, which lifts their effectivity during the seminars and exercises. The meetings in science clubs may be equally attractive form of education. During the meetings, the student may further develop his range of knowledge, which allows him to get to the more sophisticated level of education so as to teach them how to think in a creative way and to come up with original ideas, the processes, that seem to be of the greatest importance. The scientific club activity should include the students' individual likings for and predispositions. So as to serve their purpose, such clubs should guarantee to the students the comfort in their work, independence, the appropriate atmosphere, the discrete management of all of the student's progress, abilities and hobbies by the teacher. Each year's completion of the club's activity may be prepared in form of the social meeting, in connection with the graduation ceremony. Usually, such meetings enhance the connection between the emencees and the students, while simultaneously being an additional motivational agent (4, p. 28).

There is multiplicity of ways to work with a gifted student: work in groups of the same level of abilities, where the more sophisticated questions are meant for more skilled groups, team work, where the gifted students serve as the leaders and the task may be considered as a form of competition. In case of the teachers, the situation may be much more problematic, though sometimes parents want to see in their child the realisation of their unrealised aspirations. They charge the child with an overwhelming dose of expectations. It becomes the reason for the exorbitant demands on him. Parents sometimes want to see your child more talented than it actually is. This provides the teacher a lot of trouble, because they require in order to devote most attention to their child, treating him as a child outstanding. The time-consuming process of creating a work schedule is another problem. All of the situations mentioned above are supplemented by other problems of various type, like the financial problems.

\section{Characteristics of the teacher of the skilled pupil or skilled student}

The process of educating gifted students and pupils requires from the teacher an appropriate preparation to work with such people. Unfortunately, frequently such students' potential is recognized either too late or never. The professional teachers, prepared for such a task, are able to understand their students. Moreover, they possess huge knowledge and creative ability. Feeling, that their mission has a purpose, they are able to feel empathy, to apply the educational program to the children's needs, to recognize their progress and to be satisfied with their successes. While ensuring trust to their wards, they simultaneously pose high requirements for them. They do so because of high standards of their teaching. They encourage students to complete the task perfectly and appreciate their expressive creativity. The gifted pupil and student's teacher is their first student. The teacher encourages them for further education, being objective in making assessments. It is also important to establish an appropriate student-teacher relation by ensuring the student, that the teacher is a trustful person, that he cares about his wards' successes, that he or she will always be supporting their development (12).

The element, that guarantees success on the didactic field is the encouragement of students to make self-assessment, allowing them to grasp the scope of their lack of knowledge, to determine the skills they have perfected, to mark the purposes of the team work, to work in an independent way and to independent work with the teacher. Self-assessment allows the student to understand the reason behind the specific mark. Motivating the students to work, it prevents any accusations of unjustly way of marking, it prepares the student for the (ending marks announcement). It is 
undoubtedly important to show the students their work, so that they are able to learn on their mistakes, to encourage them to improvement, to analyze their mistakes and to show them the right way and goals. The educator's task is to be helpful for the students in the work organization, in order to acquire the best possible results out of such a collaboration. The educational development should take place in friendly atmosphere, full of politeness, sympathy, cooperation and encouragement. Acceptation and security are necessary in the process of increasing the student's activity. Without them, any kind of effort put into the work will be fruitless. In this case, sometimes it may be necessary to cooperate with other teachers. Another program helping in the process of interests' development is The Students And Doctoral's Mobility (polish: MOST). The program allows the students to continue studies on an university other than the one they assigned to either throughout one term or the whole academic year. The participation in the program is free of charge, no matter of the studies' mode. MOST allows to:

1. Realize the studies' program on other universities;

2. Make choice over additional didactic classes, connected with the students' area of interest;

3. Contact the specialists from specific field, working at the universities other than the one they have applied to;

4. Make the use out of the book collections of the other universities;

5. Make a seminary, master degree or doctoral thesis on the field connected with the analysis' subject;

6. Make the contacts with the scientific environment from other departments, institutes or cathedrals;

7. Demonstrate by the students their adaptation ability and mobility in front of their future employers.

The gifted students support propositions are based on the following methods of activity:

1. Tutoring development to the long-term collaboration process (lasting through at least one season), directed towards the integral student's development, concerning all of the knowledge, abilities and attitudes. The individual meetings of the students or the group with its number not exceeding four members. During the classes progression, the tutor allows the ward to know themselves, to get them familiarized with the specific knowledge area, to develop the ability of making the educational progress by themselves and to maximum utilization of their talents. The tutor embracing the students with his or her protection should have a Reader or $\mathrm{PhD}$ title. The opportunity of choosing the tutor, that would meet the expectations in terms of scientific and personality area, by the students themselves.

2. The mentoring process development. Mentoring is a partnership-type of collaboration between a master and a student. Its goal is discovery and development of the student's potential. The process is based on inspiration, stimulation, advise, the quality evaluation of the student's activities and achievements and pointing the areas of further development.

3. Having received their deans' agreement, the students with the exceptional skills have the opportunity to participate in the additional courses in terms of the Department and University establishment.

4. Initiation of the "Professor's Assistant program - having discussed the matter with the researcher at the university, the student is legitimized to lead the group of interested students, pointed by the professor, according to his or her own conception of solving the scientific problem, in accordance to the higher grade - younger students system.

Having completed the project, the student receives the University certificate. The interviews with the students suggest a few other projects to support the gifted students: 
5. The practical references for the students engaged in an exceptional degree into the didactic process and its practical relations, realized for example in form of volunteer.

6. The establishment of cooperation with the institutions the student could be sent on practical training to. Such a cooperation would be precisely documented. "The Project Out Of The Idea" a training program concerning acquiring the means for one's own research or career development from the structural funds.

It may occur, that the teacher has problems in meeting with their expectations. Their authority may be endangered by the gifted students, who exhibit knowledge of a higher level than the teacher. As a result, the teacher may become concerned about losing his or her position.

\section{Summary}

Working with gifted students and pupils is simultaneously an pleasureable, absorbing and difficult occupation. It is a time-consuming process, requiring much more attention and engagement from the teacher. However, it may be equally profitable for the teachers, as well as their students. Thanks to work with a gifted student, a teacher has the chance to improve their educating skills and to deepen their experience. The accurately motivated and supported by teacher student may not only discover their own abilities but also learn how to make a use out of them (4). Establishing a suitable atmosphere is especially important, so that students can develop their talents in the best way possible. It should not be restricted just to the cognitive, emotional or social development. The students' educational development should not be considered as one-way process, focused just on one field. The ward should be educated in a harmonical and universal way (3, p. 214). Different forms of activity should be utilized and applied to various ways of learning (with the division on visualisers, audiles and kinetics), in order to significantly increase the work efficiency. A few conditions have to be met, if the work with the gifted students is to ne successful: the academic teacher should be invested into the collaboration with the gifted students; he or she has to devote their time in the process of the classes' organisation; to recognize the students' abilities, skills and special interests and include them in the process of teaching. However, the group should not exceed 30 members; it has to have as many gifted students in its ranks so as to make the division into groups possible. The individual supervision over the pupils and students' educations equally important. At least a few stutends should cooperate with the teacher (3, p. 18). It is a great responsibility for the teacher not only to recognize a gifted student, but also to mamage their development in a suitable way. To extract the child's skills and develop them appropriately is an easy task. Because every student has different needs, it is especially important to support their abilities. Leading to unleash them is the task meant for the teachers able to get engaged in the process of an exquisite human being creation (2, p. 214).

\section{Bibliografia}

1. BAŁAŻAK M., Wiedza i umiejętności nauczyciela we współczesnej szkole, Politechnika Radomska Wydawnictwo, Radom 2009.

2. BANAR J., Uczeń idealny a uczeń twórczy $w$ percepcji nauczyciela wczesnej edukacji, Nauczanie Początkowe, nr 9, 2009/2010.

3. BORZYM I., Uczniowie zdolni, Warszawa 1979.

4. CHABER - DĄDALA A., Dzieci zdolne wymagaja troski, Edukacja i Dialog, nr 9, 2004.

5. GASIK J., Pedagog specjalny $w$ ksztaltowaniu uczniów ze specjalnymi potrzebami edukacyjnymi, [w:] Dydaktyka specjalna w przygotowaniu do kształcenia uczniów ze specjalnymi potrzebami edukacyjnymi, J. Głodkowska (red.), Wyd. APS, Warszawa 2010.

6. GIZA T., Sytuacja dzieci uzdolnionych $w$ grupie przedszkolnej, Nauczanie Początkowe, nr 3, 2003/2004. 
7. GLINKA A.M, Jak rozwijać zdolności i zainteresowania uczniów, Życie Szkoły, nr 2, 2010.

8. JAKUBIAK-ZAPALSKA E., Nauczyciel twórczy jako artysta, [w:] Drogi i bezdroża kształcenia nauczycieli w Polsce, F. Szlosek (red.), Wyd. WSI, Radom 1995.

9. JAKUBIAK-ZAPALSKA E., Uczeń zdolny $i$ jego rozpoznawanie, [w:] Badania międzynarodowe wzory zagraniczne w diagnostyce edukacyjnej, B. Niemierko, M. K. Szmigiel (red.), Wyd. Polskie Towarzystwo Diagnostyki Edukacyjnej, Kielce 2009.

10. JAKUBIAK-ZAPALSKA E., Uwarunkowania środowiskowe wsparcia ucznia zdolnego, Wyd. UTH, Radom 2013.

11. KOZŁOWSKI W., MOSKWA M., JAKUBIAK-ZAPALSKA E., Psychologia ogólna w zarysie, Wyd. Politechnika Radomska, Radom 1998.

12. LIMONT W., Uczeń zdolny. Jak go rozpoznać i jak z nim pracować, Warszawa 2005.

13. ŁEBECKA G., Uczeń zdolny w szkole, Dyrektor Szkoły, nr 2, 2005.

14. ŁEBECKA G., Rola wychowawcy w pracy z uczniem zdolnym, Dyrektor Szkoły, nr 2, 2005.

15. MILERSKI B, ŚLIWERSKI B., Pedagogika, Warszawa, 2000.

16. OKOŃ W., Nowy Stownik Pedagogiczny, Warszawa 2001.

17. OLCZAK M., Podmiotowy charakter wychowania politechnicznego, „Edukacja Humanistyczna" nr 2 (25), 2011.

18. OLCZAK M., Podmiotowy $i$ twórczy wymiar wychowania politechnicznego, Łódź, Wydawnictwo Politechniki Łódzkiej, 2012.

19. OLCZAK M., Trening twórczości - współczesna i efektywna forma wychowania przez sztukę, Oficyna Wydawnicza „Impuls”, Kraków 2009.

20. PETLAK E., Rola nauczyciela we współczesnej szkole, Wyd. Akademickie Żak, Warszawa 2008.

21. PAWELEC L., Wplyw nauczycieli na rozwój ucznia zdolnego w klasach I-III, Nauczanie Początkowe, nr 3, 2009/2010.

22. POPEK S., Zdolności i uzdolnienia - ujęcie systemowe problemu, Lublin 1996.

23. ROSTKOWSKA M., Praca z uczeniem zdolnym w szkole średniej, Meritum, nr 2, 2006.

24. SĘKOWSKI A.E., Porozmawiajmy o uczniach zdolnych, [w:] Psychologia w Szkole, nr 3/3 2004.

25. WINIARCZYK A., O specyfice pracy z uczniem zdolnym, Nauczanie Początkowe, nr 3, 2010.

\section{Contact Address:}

Ewa Jakubiak-Zapalska, Ph.D.

UTH Radom,

ewa.jakubiak-Zapalska@wp.pl

Ewa Zapalska,

UAM Olsztyn 